\title{
PENGARUH E-LEARNING MOODLE BERORIENTASI PROJECT BASED LEARNING TERHADAP PRESTASI BELAJAR SISWA (Studi Kasus : Kelas X Desain Komunikasi Visual Pada Mata Pelajaran Sketsa Di SMK Negeri 1 Sukasada)
}

\author{
Ni Nyoman Widya Astiti', Ketut Agustini², Gede Saindra Santyadiputra ${ }^{3}$ \\ Program Studi Pendidikan Teknik Informatika \\ Jurusan Teknik Informatika \\ Universitas Pendidikan Ganesha \\ Singaraja, Bali \\ e-mail : nyoman.widya.astiti@undiksha.ac.id ${ }^{1}$, ketutagustini@undiksha.ac.id ${ }^{2}$, gsaindras@undiksha.ac.id ${ }^{3}$
}

\begin{abstract}
ABSTRAK
Penelitian ini bertujuan untuk mengetahui (1) perbedaan prestasi belajar antara siswa yang belajar menggunakan E-learning Moodle dan siswa yang belajar menggunakan media PowerPoint pada mata pelajaran Sketsa kelas X DKV di SMK Negeri 1 Sukasada (2) mengetahui respon siswa kelas X DKV di SMK Negeri 1 Sukasada setelah menggunakan $E$ learning Moodle. Jenis penelitian ini adalah eksperimen semu (quasi eksperimen) dengan desain Post Test Only Control Group Design. Populasi penelitian mencakup seluruh siswa kelas X Desain Komunikasi Visual di SMK Negeri 1 Sukasada Tahun Pelajaran 2018/2019. Metode pengumpulan data yang digunakan yaitu dengan metode tes uraian untuk mengatur ranah kognitif kemudian dianalisis dengan meliputi uji normalitas, uji homogenitas dan uji hipotesis dan metode kuisioner
\end{abstract}

\section{ABSTRACT}

This research aimed to know (1) the differentiation of students' achievement among students who learned using E-Learning Moodle and students who learned using PowerPoint on Sketch subject in X DKV class in SMK Negeri 1 Sukasada (2) to know X DKV students' in SMK Negeri 1 Sukasada responses after using $E$ Learning Moodle. This research was quasi experimental research which using Post Test only Control Group design. Population of this research were all X DKV students in SMK Negeri 1 Sukasada in academic year 2018/2019. Data collection method used in this research was essay test to settle the cognitive domain then analyzed using normality test, homogeneity test, and hypothesis test also questionnaire to know the students' responses. The result of students' achievement then untuk melihat respon siswa. Data hasil belajar kemudian dianalisis dengan melakukan uji prasyarat yang meliputi uji normalitas, uji homogenitas dan uji- t. Hasil penelitian menunjukkan (1) bahwa terdapat perbedaan prestasi belajar antara siswa yang belajar menggunakan E-learning Moodle dan siswa yang belajar menggunakan media PowerPoint pada mata pelajaran Sketsa kelas X DKV di SMK Negeri 1 Sukasada. Hasil analisis uji-t memperoleh $t_{\text {hitung }}$ sebesar 4.518704 dan $\mathrm{t}_{\text {tabel }}$ sebesar 2.005746 untuk dk $\mathrm{t}_{\text {hitung }}>\mathrm{t}_{\text {tabel, }}$, ini berarti $\mathrm{H}_{0}$ ditolak. (2) respon siswa dari penerapan E-learning Moodle adalah sangat positif dilihat dari rata-rata skor hasil angket respon siswa yaitu 83,04\%.

Kata kunci : E-learning Moodle ,Prestasi Belajar, Sketsa, respon siswa

analyzed by conducting regulation test, such as normality test, homogeneity test, and T-test. Result of the research shows that (1) there is different achievement among the students who learned using ELearning Moodle and students who learned using PowerPoint media on Sketch subject in X DKV class in SMK Negeri 1 Sukasada. The results of the t-test analysis obtained $t_{\text {count }}$ of 4.518704 and $t_{\text {table }} 2.005746$ for $t_{\text {count }}>t_{\text {table }}$ It means that $\mathrm{H}_{0}$ is rejected. (2) students' responses from the implementation of E-Learning Moodle is very positive which can be seen from the mean score from students' questionnaire which is $83.04 \%$

Key Words : E-Learning Moodle, students' achievement, Sketch, Students' responses 


\section{PENDAHULUAN}

Perkembangan Ilmu Pengetahuan dan Teknologi (IPTEK) khususnya teknologi informasi dan komunikasi saat ini sudah banyak menawarkan kemudahan, kemudahan yang ditawarkan salah satunya terdapat pada bidang Pendidikan. Kemudahan tersebut sudah banyak memberikan dampak yang positif pada pemanfaatan TI sebagai alat bantu dalam proses pembelajaran yang lebih efektif dan efisien. Salah satu pemanfaatan TI dalam bidang pendidikan adalah E-learning sebagai media pembelajaran. Penggunaan E-learning sebagai media pembelajaran merupakan sarana untuk meningkatkan mutu pendidikan.

Penerapan E-learning dapat memberikan pengalaman yang menarik dan bermakna bagi siswa karena dapat berinteraksi langsung, sehingga pemahaman terhadap materi akan lebih bermakna, mudah dipahami dan diingat [1]. Dalam (Permendikbud No. 103 Tahun 2014) menjelaskan kurikulum 2013 menggunakan 3 (tiga) model pembelajaran salah satunya adalah Project Based Learning. Pembelajaran berbasis proyek merupakan model pembelajaran yang melibatkan siswa secara aktif dalam merancang tujuan pembelajaran untuk menghasilkan produk atau proyek yang nyata [2]. Pernyataan tersebut sesuai dengan proses pembelajaran yang ada di sekolah menengah kejuruan (SMK).

SMK Negeri 1 Sukasada merupakan salah satu sekolah menengah kejuruan Seni dan Teknologi yang terletak di Bali Utara. Saat ini SMK Negeri 1 Sukasada memiliki 9 kompetensi keahlian, salah satunya adalah jurusan Desain Komunikasi Visual. Berdasarkan observasi awal yang dilakukan dengan teknik wawancara terhadap guru pengampu mata pelajaran Sketsa diperoleh data bahwa sumber belajar ataupun bahan ajar yang dipakai untuk kegiatan belajar mengajar bersumber dari materi yang diberikan guru, media PowerPoint dan referensi pada Youtube ataupun internet, sehingga mengakibatkan pembelajaran masih berpusat pada guru, dan siswa senang mencari materi di internet yang belum memiliki sumber yang jelas. Tinjauan tentang sarana dan prasarana untuk memanfaatkan E-learning sudah memadai. Karena pada jurusan Desain Komunikasi Visual sudah menyediakan media pembelajaran E-learning Moodle sebagai alat bantu dalam proses pembelajaran. Namun penggunaannya yang belum optimal digunakan oleh guru di jurusan Desain Komunikasi Visual.

Karakteristik siswa kelas X di jurusan Desain Komunikasi Visual sebagian besar sangat aktif dan motivasi belajar siswa sangat tinggi, namun karena media pembelajaran yang bersifat monoton menyebabkan sebagian siswa konsentrasinya dalam pembelajaran masih kurang dan cenderung hanya sekedar mendengarkan penjelasan dari guru. Mata pelajaran sketsa adalah salah satu mata pelajaran produktif yang ada di SMK Negeri 1 Sukasada dimana kurikulum yang digunakan adalah kurikulum 2013. Konsep dari pembelajaran tersebut adalah menekankan siswa pada keaktifan dan kreativitasnya dalam proses pembelajaran. Berdasarkan dari data nilai siswa yang didapat, masih banyak siswa yang belum memenuhi standar Kriteria Ketuntasan Minimum (KKM) yaitu 80. Hal tersebut dapat dilihat pada nilai persentase UAS yang dicapai siswa kelas X DKV semester ganjil sebelumnya pada mata pelajaran sketsa tahun pelajaran 2018/2019. Terlihat bahwa tingkat persentase nilai siswa pada tahun pelajaran 2018/2019 yang mencapai KKM sebanyak $31.14 \%$ dan siswa yang persentase nilainya tidak dapat mencapai KKM yaitu sebanyak $68.86 \%$. Nilai tersebut adalah hasil dari nilai UAS yang belum mendapatkan remidial dari guru. Hal ini membuktikan bahwa masih ada siswa yang nilainya berada di bawah KKM yang perlu dilakukan bimbingan lebih lanjut.

Berdasarkan permasalahan-permasalahan yang sudah dijelaskan sebelumnya, terlihat bahwa bahan ajar berperan penting dalam proses pembelajaran. Dari hal tersebut, tentu perlu dukungan media pembelajaran agar seluruh materi yang ada bisa didapatkan oleh siswa dan sumber belajar lebih mudah didapatkan. Salah satu media pembelajaran yang sudah diterapkan yaitu $E$ learning Moodle. SMK Negeri 1 Sukasada sudah memiliki Link tersendiri untuk mengaksesnya yaitu di dkvsmik.gnomio.com. Moodle memiliki berbagai fitur, fitur-fitur penting penunjang pembelajaran tersebut misalnya tugas, quiz, komunikasi, kolaborasi, serta fitur utama yang dapat mengupload berbagai format materi pembelajaran [3]. Moodle dapat diakses oleh siswa melalui perangkat yang terhubung dengan internet yang dilengkapi dengan peramban web atau menggunakan Smartphone, PC/Komputer, dan Laptop. Kegunaan dari E-learning Moodle sebagai wadah atau tempat mengerjakan tugas yang diberikan guru, baik tugas dalam bentuk soal latihan atau berupa proyek karena dalam penguploadan file nya siswa dapat mengupload berbagai format file. Kemudian siswa dapat mengakses materi pelajaran, jika ada kesulitan siswa dapat mengirimkan melalui menu pesan tentang materi yang belum dipahami. Siswa juga dapat mengikuti quiz secara Online dan dapat melihat langsung hasil dari nilai yang didapatkannya. Berkaitan dengan hal tersebut penggunaan E-Learning Moodle dalam pembelajaran diharapkan dapat mendukung tercapainya peningkatan hasil belajar siswa khususnya pada pelajaran sketsa. Posisi peneliti di sini hanya membantu mempersiapkan konten pembelajaran yang akan diberikan kepada siswa dan mempersiapkan bahan ajar lainnya untuk proses pembelajaran yang berlangsung di kelas. 
Berdasarkan penelitian yang sebelumnya yang dilakukan terkait dengan penelitian media pembelajaran E-Learning Moodle, didapatkan beberapa hasil penelitian yang relevan dengan media pembelajaran $E$ Learning Moodle, penelitian terkait yang dilakukan oleh [4] dengan judul "Pengaruh Media Pembelajaran ( $E$ Learning Moodle, Lks) Dan Motivasi Terhadap Hasil Belajar Pengoperasian Perangkat Lunak Lembar Sebar Di SMKN 1 Mojokerto", dari penelitiannya menyatakan bahwa dengan menggunakan media e-learning moodle terdapat hasil belajar yang lebih baik dibandingkan dengan penggunaan LKS, pada siswa yang memiliki motivasi belajar yang tinggi hasil belajarnya lebih baik dari pada siswa yang bermotivasi belajar rendah, Dari hasil uji hipotesis dengan teknik Anava pada uji hipotesis pertama diperoleh Fhitung = 7,923 dengan signifikansi 0,007. Pada uji hipotesis kedua diperoleh Fhitung untuk motivasi adalah 108,142 dengan signifikansi 0,000. dan pada uji hipotesis ke tiga diperoleh Fhitung $=8,369$ dengan signifikansi 0,005 . Terkait juga dengan penelitian [5] dengan judul "Penerapan Media Pembelajaran E-learning Berbasis Moodle Pada Mata Pelajaran Ilmu Bangunan Gedung Di Kelas X TGB SMKN 1 Kediri", Hasil penelitian yang diperoleh menunjukkan bahwa (a) Hasil validasi moodle adalah 4.07 yang berada dalam kategori Valid/Baik sehingga dapat digunakan sebagai media pendamping guru dalam proses pengajaran; (b) Hasil keseluruhan keterlaksanaan pembelajaran dengan rata-rata nilai dari hari pertama dan kedua mendapatkan nilai sebesar 4.11 yang termasuk dalam kategori Sangat Sesuai. (c) Rata-rata nilai hasil belajar siswa adalah 83,1 yang berarti hasil belajar siswa kelas X TGB SMK Negeri 1 Kediri setelah penggunaan media e-learning berbasis moodle adalah lebih besar dari KKM 75 dapat diterima; (d) siswa tertarik dan dapat menerima terhadap pembelajaran menggunakan elearning berbasis moodle dengan persentase hasil respons sebesar $73.99 \%$.

Adapun penelitian yang relevan terkait dengan model pembelajaran Project Based Learning, Penelitian yang dilakukan oleh [6] dengan judul "Pengaruh Penggunaan Model Pembelajaran Project Based Learning pada Pembelajaran Sejarah Terhadap Hasil Belajar Siswa Kelas XI IPS MAN Temanggung". Pada teknik analisis data yang digunakan adalah menghitung hasil belajar kognitif yakni Uji normalitas, Uji homogenitas, Uji regresi. Hasil uji t diperoleh nilai thitung sebesar 3,746 dengan nilai signifikansi 0,000< 0,05. Hal ini berarti $\mathrm{H} 0$ ditolak dan Ha diterima, sehingga hipotesis yang menyatakan ada pengaruh positif antara model pembelajaran Project Based Learning dengan hasil belajar. Berdasarkan uji ANOVA tersebut nilai Fhitung sebesar 14,035 dengan nilai signifikansi 0,001. Karena nilai signifikansi $<0,05$ maka H0 ditolak dan menerima Ha, sehingga hipotesis yang berbunyi ada pengaruh positif antara model pembelajaran proyek based learning $(\mathrm{X})$ terhadap hasil belajar kelas XI IPS 1 MAN Temanggung diterima.

Berdasarkan permasalahan yang terdapat di lapangan, adapun masalah yang teridentifikasi adalah masih banyak guru yang belum mengoptimalkan pemanfaatan TI sebagai alat bantu dalam proses pembelajaran yang diduga menyebabkan rendahnya hasil belajar siswa. Sehingga penulis ingin mengetahui apakah E-learning dapat mempengaruhi hasil belajar siswa. Berdasarkan hal tersebut penulis tertarik untuk menerapkan E-Learning Moodle dengan model pembelajaran yang sudah diterapkan sebelumnya yaitu Project Based Learning dalam mata pelajaran sketsa melalui penelitian yang berjudul "Pengaruh $\boldsymbol{E}$ Learning Moodle Berorientasi Project Based Learning Terhadap Hasil Belajar Siswa (Studi Kasus: Kelas X Desain Komunikasi Visual Pada Mata Pelajaran Sketsa Di SMK Negeri 1 Sukasada).

\section{KAJIAN TEORI}

\section{A. Teori Belajar}

Belajar adalah perubahan yang terjadi dalam kemampuan manusia setelah belajar secara terus menerus, bukan hanya disebabkan karena proses pertumbuhan saja. Gagne berkeyakinan bahwa belajar dipengaruhi oleh faktor dari luar diri dan faktor dalam diri dan keduanya saling berinteraksi. Ada empat kategori utama atau kerangka filosofis mengenai teoriteori belajar, yaitu: teori belajar behaviorisme, teori belajar kognitivisme, teori belajar konstruktivisme dan teori belajar Connectivism.

Teori belajar behavioristik adalah perubahan tingkah laku sebagai akibat dari adanya interaksi antara stimulus dan respon. Dengan kata lain, belajar merupakan bentuk perubahan yang dialami siswa dalam hal kemampuannya untuk bertingkah laku dengan cara yang baru sebagai hasil interaksi antara stimulus dan respon.

Teori belajar kognitivisme merupakan suatu proses internal yang mencakup ingatan, retensi, pengolahan informasi, emosi, dan aspek-aspek kejiwaan lainnya. Oleh karena itu, teori kognitivisme lebih mementingkan proses belajar dari pada hasil belajar itu sendiri.

Teori belajar konstruktivisme mengemukakan bahwa realitas ada pada pemikiran seseorang. Manusia mengonstruksi dan menginterpretasikannya berdasarkan pengalamannya. Pandangan konstruktivisme belajar sebagai sebuah proses di mana pelajar aktif membangun atau membangun ide-ide baru atau konsep.

Teori connectivism diperkenalkan George Siemen. Connectivism merupakan teori pembelajaran yang digunakan untuk era digital masa kini dan merupakan alternatif teori pembelajaran pada abad digital. Teori connectivism dinilai dapat membentuk siswa agar 
ISSN 2252-9063

Kumpulan Artikel Mahasiswa Pendidikan Teknik Informatika

(KARMAPATI)

Volume 8 Nomor 2 Tahun 2019

mampu berpikir lebih kritis dalam menerima informasiinformasi yang didapatkan di dalam belajar.

\section{B. Media Pembelajaran}

Istilah "media" berasal dari bahasa Latin dan merupakan bentuk jamak dari "medium" yang secara harafiah berarti perantara atau penghantar. Media merupakan komponen sumber belajar atau wahana fisik yang mengandung materi instruksional di lingkungan siswa yang dapat merangsang siswa untuk belajar [2]. Tentunya, penggunaan media dibutuhkan sebagai alat komunikasi untuk membawa informasi dari pengajar ke peserta didik. Tujuannya yaitu agar dapat merangsang peserta didik untuk mengikuti proses pembelajaran serta mengantarkan pembelajaran secara utuh dalam memberikan penguatan atau motivasi. Salah satu teori yang paling banyak dijadikan acuan sebagai landasan teori penggunaan media dalam proses belajar adalah Dale's Cone of Experience (Kerucut pengalaman Dale) [7] berikut adalah gambaran kerucut pengalaman Dale :

\section{Dale's Cone of Experience}

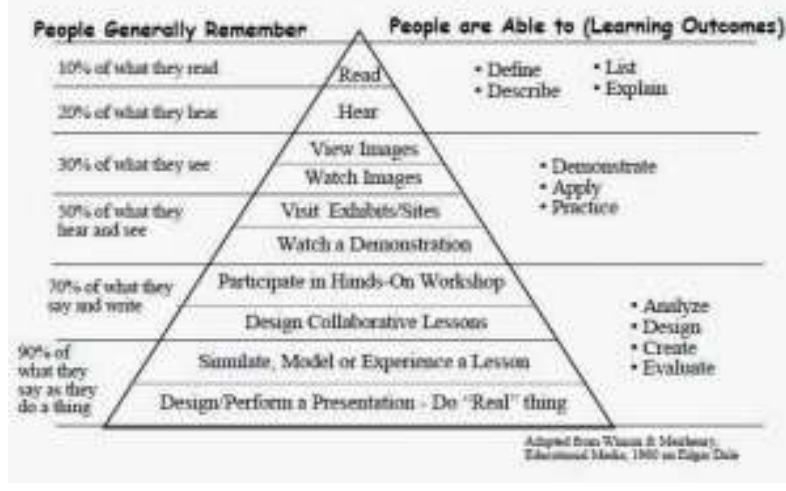

Gambar 1. Kerucut Pengalaman Dale

Sumber : (Arsyad, 2013, h.10).

Hasil belajar seseorang menurut Dale diperoleh mulai dari pengalaman langsung (kongkret), kenyataan yang ada dilingkungan kehidupan seseorang kemudian melalui benda tiruan, sampai kepada lambang verbal (abstrak). Semakin nyata (kongkret pesan itu maka semakin mudah bagi peserta didik mencerna materi yang diberikan. berkaitan dengan simbol verbal dan visual sendiri, maka guru sebisa mungkin menggambarkan dan memvisualisasikan sehingga benak peserta didik mampu mencernanya dengan baik.

\section{E-Learning Moodle}

E-Learning bisa diartikan sebagai pembelajaran dengan memanfaatkan bantuan perangkat elektronik, khususnya perangkat komputer. Fokus paling penting dalam e-learning adalah proses belajarnya (learning) itu sendiri, dan bukan pada " $e$ " (electronic), karena elektronik hanyalah sebagai alat bantu saja. Pelaksanaan e-learning menggunakan bantuan audio, video, dan perangkat komputer atau kombinasi dari ketiganya [1].

Moodle adalah sebuah aplikasi Course Management System (CMS) yang dapat digunakan oleh siapa saja secara open source. Dengan menggunakan Moodle dapat membangun sistem dengan konsep E-learning (pembelajaran secara elektronik). Aplikasi ini memungkinkan siswa untuk masuk ke dalam "ruang kelas" digital untuk mengakses materi pembelajaran, kuis, jurnal elektronik dan lain-lain. Moodle memiliki beberapa fitur unggulan seperti : pengajuan tugas, forum diskusi, unduh arsip, peringkat, chat, kalender online, berita, kuis online dan lainnya.

E-learning Moodle memberikan kemudahan bagi guru untuk mengirim tugas ke perangkat mobile yang dimiliki oleh siswa. Manfaat bagi siswa yaitu E-learning Moodle dapat digunakan sebagai tempat siswa untuk mengerjakan tugas yang diberikan guru, mengakses seluruh materi pelajaran, dan mengirimkan pesan kepada guru mengenai kesulitan belajar yang dihadapi. $E$ learning Moodle dapat diakses oleh siswa melalui perangkat yang terhubung dengan internet yang dilengkapi dengan peramban web atau menggunakan Smartphone, PC/Komputer, Laptop dan Tablet. Siswa dapat mengakses E-learning Moodle kapan saja dan dimana saja.

\section{Model Pembelajaran}

Model pembelajaran adalah kerangka konseptual yang melukiskan prosedur yang sistematis dalam mengorganisasikan pengalaman belajar untuk mencapai tujuan belajar tertentu, dan berfungsi sebagai pedoman bagi para perancang pembelajaran dan para pengajar dalam merencanakan dan melaksanakan aktivitas pembelajaran benar-benar merupakan kegiatan bertujuan yang tertata secara sistematis. Pembelajaran berbasis proyek adalah suatu metode pengajaran sistematis yang melibatkan para siswa dalam mempelajari pengetahuan dan keterampilan melalui proses yang terstruktur, pengalaman nyata, dan teliti yang dirancang untuk menghasilkan produk. Tujuan dari model pembelajaran Project Based Learning (PjBL) yaitu (1) meningkatkan kemampuan peserta didik dalam memecahkan masalah; (2) memperoleh pengetahuan dan keterampilan baru dalam pembelajaran; (3) membuat peserta didik lebih aktif dalam memecahkan masalah proyek yang kompleks dengan hasil produk nyata; dan (4) mengembangkan dan meningkatkan keterampilan peserta didik dalam mengelola bahan atau alat untuk menyelesaikan tugas atau proyek.

E. Prestasi Belajar 
ISSN 2252-9063

Kumpulan Artikel Mahasiswa Pendidikan Teknik Informatika

(KARMAPATI)

Volume 8 Nomor 2 Tahun 2019

Prestasi belajar adalah suatu usaha yang dilakukan seseorang untuk memperoleh suatu perubahan tingkah laku yang baru secara keseluruhan melalui proses pembelajaran yang telah dilakukan. terdapat dua faktor yang mempengaruhi prestasi belajar siswa, yaitu faktor intern dan faktor ekstern. Faktor intern adalah faktor yang berasal dari dalam diri siswa itu sendiri, sedangkan faktor ekstern adalah faktor yang berasal dari luar diri siswa. Faktor intern yang mempengaruhi prestasi belajar adalah kematangan fisik dan mental, kecerdasan, pengetahuan dan keterampilan, minat dan motivasi serta faktor karakteristik pribadi

\section{METODOLOGI}

\section{A. Jenis Penelitian}

Jenis penelitian yang digunakan dalam penelitian ini adalah jenis penelitian eksperimen. Desain penelitian eksperimen yang digunakan adalah eksperimen semu atau biasa juga disebut eksperimen quasi. Dikatakan sebagai eksperimen semu karena tidak semua variabel dan kondisi eksperimen dapat diatur dan kontrol secara ketat. Pada penelitian ini diberikan perlakuan yang berbeda antara ke dua kelas sampel yang digunakan. Kelas pertama sebagai kelas eksperimen akan diberikan perlakuan berupa penambahan penggunaan media pembelajaran berupa E-learning Moodle pada mata pelajaran Sketsa, sedangkan kelas kedua sebagai kelas kontrol akan diberikan perlakuan belajar menggunakan media PowerPoint (metode konvensional) pada mata pelajaran yang sama yaitu Sketsa.

\section{B. Tempat Dan Waktu Penelitian}

Penelitian ini dilaksanakan di SMK Negeri 1 Sukasada kelas X Desain Komunikasi Visual. Waktu pelaksanaan penelitian ini adalah rentangan waktu semester genap pada tahun ajaran 2018/2019.

\section{Populasi Dan Sampel Penelitian}

1. Populasi

Populasi dalam setiap penelitian harus disebutkan secara tersurat yaitu yang berkenaan dengan besarnya anggota populasi serta wilayah penelitian yang dicakup. Tujuan diadakannya populasi ialah agar kita dapat menentukan besarnya anggota sampel yang diambil dari anggota populasi dan membatasi berlakunya daerah generalisasi. Populasi dalam penelitian ini adalah kelas $\mathrm{X}$ Desain Komunikasi Visual semester genap SMK Negeri 1 Sukasada tahun ajaran 2018/2019. Distribusi jumlah siswa kelas $\mathrm{X}$ Desain
Komunikasi Visual di SMK Negeri 1 Sukasada pada tahun 2018/2019 disajikan pada Tabel 1.

Tabel 1 Populasi Penelitian

\begin{tabular}{|c|c|c|}
\hline No & Kelas & Jumlah Siswa \\
\hline 1 & X DKV 1 & 27 \\
\hline 2 & X DKV 2 & 28 \\
\hline \multicolumn{2}{|c|}{ Jumlah } & 55 \\
\hline
\end{tabular}

2. Sampel

Sampel adalah sebagian kecil dari jumlah dan karakteristik yang dimiliki oleh populasi. Teknik pengambilan sampel dalam penelitian ini yaitu dengan cara random sampling, dan yang di random adalah kelas. Cara ini dipilih karena sulit mengubah kelas yang sudah terbentuk. Kelas dipilih sebagaimana telah terbentuk tanpa campur tangan peneliti sehingga kemungkinan pengaruh-pengaruh dari keadaan subjek mengetahui dirinya dilibatkan dalam eksperimen dapat dikurangi sehingga penelitian ini benar-benar menggambarkan pengaruh perlakuan yang diberikan. Berdasarkan hasil pengundian dengan teknik simple random sampling maka ditetapkan kelas X DKV 1 sebagai kelompok eksperimen dan kelas DKV 2 sebagai kelas kelompok kontrol Perbandingan kelas kontrol dan eksperimen dapat dilihat pada Tabel 2.

Tabel 2 Sampel Penelitian

\begin{tabular}{|l|c|c|}
\hline \multicolumn{1}{|c|}{ Kelompok } & Kelas & $\begin{array}{c}\text { Jumlah } \\
\text { Siswa }\end{array}$ \\
\hline Kontrol & X DKV 1 & 27 \\
\hline Eksperimen & X DKV 2 & 28 \\
\hline \multicolumn{2}{|c|}{ Jumlah } & 55 \\
\hline
\end{tabular}

D. Variabel Penelitian

Variabel adalah segala faktor, kondisi, situasi, perlakuan (treatment) dan semua tindakan yang bisa dipakai untuk mempengaruhi hasil eksperimen. Karena penelitian eksperimen untuk melihat pengaruh , maka variabel itu bisa dikelompokkan menjadi variabel bebas (independent variable) dan variabel terikat atau tergantung (dependent variable).

1. Variabel Bebas

Variabel bebas adalah kondisi atau karakteristik yang oleh peneliti dimanipulasi dalam rangka untuk menerangkan hubungannya dengan fenomena yang diobservasi. Dalam bidang pendidikan, kondisi yang dimanipulasi atau segala bentuk perlakuan yang diterapkan oleh peneliti [sanjaya]. Variabel bebas dalam penelitian ini adalah media 
ISSN 2252-9063

Kumpulan Artikel Mahasiswa Pendidikan Teknik Informatika

(KARMAPATI)

Volume 8 Nomor 2 Tahun 2019

pembelajaran yang akan diteliti yaitu media pembelajaran E-learning Moodle.

2. Variabel Terikat

Variabel terikat adalah kondisi atau karakteristik yang berubah, yang muncul atau yang tidak muncul ketika peneliti mengintroduksi, mengubah, dan mengganti variabel bebas dipengaruhi oleh variabel bebas. Variabel terikat yang dalam penelitian ini adalah prestasi belajar kelas X DKV pada mata pelajaran Sketsa di SMK Negeri 1 Sukasada. Hubungan antar variabel yang akan digunakan pada penelitian ini dapat dilihat pada gambar 1 .

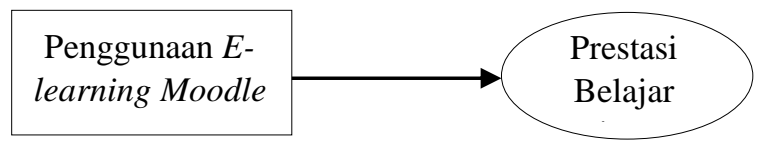

Gambar 2. Diagram Hubungan Variabel Penelitian

Keterangan :

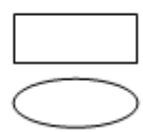

$$
\begin{aligned}
& \text { : Variabel Bebas } \\
& \text { : Variabel Terikat }
\end{aligned}
$$

E. Uji Coba Instrumen Penelitian

Sebelum perangkat pembelajaran dan instrument penelitian digunakan maka terlebih dahulu dilakukannya pengujian untuk mendapat gambaran secara empiric apakah perangkat dan instrument layak digunakan dalam penelitian. Instrumen dikatakan sesuai jika instrumen tersebut sudah memenuhi kriteria Validitas, Reliabilitas. Kualitas item, khususnya di representasi oleh Indeks Kesukaran Butir (IKB), Indeks Daya beda Butir (IDB). Untuk memperoleh tujuan dari proses analisis, data terlebih dahulu dianalisis dengan menggunakan uji validitas tes dan reliabilitas tes.

\section{Uji Validitas Isi}

Validitas isi menunjukkan sejauh mana pertanyaan, tugas atau butir dalam suatu tes atau instrumen mampu mewakili secara keseluruhan dan proporsional keseluruhan perilaku sampel yang menjadi tujuan pembelajaran yang akan diukur pencapainnya. Untuk mengetahui apakah tes itu valid atau tidak, harus dilakukan melalui penelaahan kisi-kisi tes untuk memastikan bahwa soal-soal tes itu sudah mewakili atau mencerminkan keseluruhan konten atau materi yang seharusnya dikuasai secara proporsional .

2. Uji Reliabilitas
Koefisien reliabilitas tes non dikotomi dihitung dengan menggunakan rumus Alpha Cronbach [8]:

$$
\alpha=\left(\frac{n}{n-1}\right)\left(1-\frac{\sum V i}{\sum V t}\right)
$$

Keterangan :

$\mathrm{V}_{\mathrm{i}}$ = varian bagian ke I dari tes

$\mathrm{V}_{\mathrm{t}}=$ varian skor total

$\mathrm{n}$ = banyak bagian

Kriteria yang digunakan dalam uji reliabilitas ini adalah sebagi berikut :

Tabel 3. Tingkat Reliabilitas Rumus Alpha Cronbach

\begin{tabular}{|l|c|}
\hline \multicolumn{1}{|c|}{ Nilai } & Keterangan \\
\hline $\mathrm{r} 11<0,20$ & Sangat Rendah \\
\hline $0,20 \leq \mathrm{r} 11<0,40$ & Rendah \\
\hline $0,40 \leq \mathrm{r} 11<0,60$ & Sedang \\
\hline $0,60 \leq \mathrm{r} 11<0,80$ & Tinggi \\
\hline $0,80 \leq \mathrm{r} 11<1,00$ & Sangat Tinggi \\
\hline
\end{tabular}

Semakin tinggi nilai reliabilitas dari sebuah instrument maka semakin konsisten dan dapat dipercaya instrument tersebut. Sebaliknya semakin rendah nilai reliabilitas dari instrument maka instrument tersebut tidak konsisten terhadap objek yang diukur.

\section{Uji Indeks Kesukaran Butir}

Tingkat kesukaran tes diukur dengan tujuan untuk dapat mengetahui seberapa sukar tes tersebut untuk dapat dikerjakan oleh siswa atau peserta tes. Semakin banyak siswa atau peserta tes yang dapat menjawab soal dengan benar maka taraf kesukaran tes tersebut dikatakan masih rendah. Sebaliknya semakin sedikit siswa atau peserta tes yang dapat menjawab soal dengan benar maka taraf kesukaran test dikatakan tinggi. Umumnya uji taraf kesukaran butir dilakukan dengan memperhitungkan banyak responden yang menjawab butir tersebut dengan benar. Rumus yang digunakan adalah sebagai berikut:

$$
I=\frac{\sum U+\sum L-(2 N x \operatorname{Smin})}{2 N(\operatorname{Smak}-\operatorname{Smin})}
$$

Keterangan :

$\sum \mathrm{U}=$ Total skor kelompok atas

$\sum \mathrm{L}=$ Total skor kelompok bawah

$\mathrm{S}_{\mathrm{mak}}=$ Skor maksimal butir 
$\mathrm{S}_{\min }=$ Skor minimum butir

$\mathrm{N}$ = Banyak peserta tes

Adapun pembagian tingkat kesukaran menurut Witherington sebagai berikut.

a. Butir dengan P 0,00 sampai 0,30 tergolong sukar

b. Butir dengan P 0,31 sampai 0,70 tergolong sedang

c. Butir dengan P 0,71 sampai 1,00 tergolong mudah

4. Uji Indeks Daya Beda

Daya pembeda digunakan untuk mengkaji di setiap butir soal yang dimaksudkan untuk mengetahui kesanggupan butir-butir tes untuk membedakan siswa yang tergolong mampu dengan siswa yang tergolong tidak mampu. Indeks daya beda tes hasil belajar dihitung dengan formula daya beda Ferguson. Tingkat kesukaran berpengaruh langsung pada daya pembeda soal. Indeks daya beda tes hasil belajar sesuai dihitung dengan menggunakan rumus dibawah ini.

$$
a=\frac{N^{2}-\sum \mathrm{f}_{i}^{2}}{N^{2}-\frac{N^{2}}{n+1}}=\frac{(n+1)\left(N^{2}-\Sigma f_{i}^{2}\right)}{n N^{2}}
$$

Keterangan :

$d \quad=$ Indeks daya beda

$\mathrm{N}=$ Banyak peserta tes

$f i=$ Frekuensi pada tiap-tipa skor

$\mathrm{n} \quad=$ Banyak butir

Kriteria yang digunakan dalam menentukan daya pembeda tes adalah sesuai Tabel 4 .

Tabel 4. Kriteria Uji Indeks Daya Beda

\begin{tabular}{|l|c|}
\hline \multicolumn{1}{|c|}{ Indeks Daya Beda } & Keterangan \\
\hline $\mathrm{D}<0,00$ & Sangat Jelek \\
\hline $0,00 \leq \mathrm{D}<0,20$ & Jelek \\
\hline $0,20 \leq \mathrm{D}<0,40$ & Cukup \\
\hline $0,40 \leq \mathrm{D}<0,70$ & Baik \\
\hline $0,70 \leq \mathrm{D}<1,00$ & Sangat Baik \\
\hline
\end{tabular}

\section{F. Teknik Analisis Data}

Teknik analisis data dalam penelitian ini menggunakan analisis statistik deskriptif dan statistik inferensial (uji-t) untuk menguji hipotesis penelitian. Data yang diperoleh dalam penelitian ini adalah data kuantitatif dan kualitatif. Data tersebut diolah menggunakan analisis statistik dan analisis non statistik. Data kuantitatif akan dianalisis dengan analisis statistic deskriptif untuk mendeskripsikan data hasil belajar siswa. Kemudian data kualitatif dianalisis dengan memberi makna terhadap deskripsi data. Analisis statistic digunakan untuk menggeneralisasi hasil penelitian yang meliputi estimasi (perkiraan), uji prasyarat berupa uji normalitas dan uji homogenitas, serta uji hipotesis. Sebelum dianalisis dengan uji-t data diuji prasyarat terlebih dahulu.

1. Teknik Analisis Deskriptif

Analisis deskriptif dilakukan untuk mengetahui tinggi rendahnya kualitas dari hasil belajar. Metode analisis deskriptif kuantitatif adalah suatu cara pengolahan data yang dilakukan dengan cara menyusun secara sistematis dalam bentuk angkaangka persentase, mengenai suatu objek yang diteliti sehingga diperoleh kesimpulan umum. Penentuan kualitas variabel-variabel, skor rata-rata (mean) tiap-tiap variabel dikonversikan dengan menggunakan kriteria rata-rata ideal dan standar deviasi (SD) seperti pada Tabel 5.

Tabel 5. Uji Mean Ideal dan Standar Deviasi Ideal

\begin{tabular}{|l|c|}
\hline \multicolumn{1}{|c|}{ Rentangan Skor } & Kategori \\
\hline $\mathrm{MI}+1,5 \mathrm{SDI} \leq \mathrm{X}$ & Sangat Tinggi \\
\hline $\mathrm{MI}+0,5 \mathrm{SDI} \leq \mathrm{X}<\mathrm{MI}+1,5 \mathrm{SDI}$ & Tinggi \\
\hline $\mathrm{MI}-0,5 \mathrm{SDI} \leq \mathrm{X}<\mathrm{MI}+0,5 \mathrm{SDI}$ & Sedang \\
\hline $\mathrm{MI}-1,5 \mathrm{SDI} \leq \mathrm{X}<\mathrm{MI}-0,5 \mathrm{SDI}$ & Rendah \\
\hline $\mathrm{X}<\mathrm{MI}-1,5 \mathrm{SDI}$ & Sangat Rendah \\
\hline
\end{tabular}

Keterangan :

$$
\begin{aligned}
\mathrm{X}= & \text { Kualifikasi nilai } \\
\mathrm{MI}= & \frac{1}{2}(\text { skor tertinggi ideal }+ \text { skor terendah } \\
& \text { ideal }) \\
\text { SDI }= & \frac{1}{6}(\text { skor tertinggi ideal }- \text { skor terendah } \\
& \text { ideal })
\end{aligned}
$$

\section{Teknik Uji Prasyarat Analisis}

Sebelum dilakukan uji hipotesis, data yang dikumpulkan diuji prasyarat terlebih dahulu. Uji prasyarat ini dilakukan untuk membuktikan bahwa data yang dikumpulkan layak untuk dianalisis dengan statistic parametric atau tidak. Uji prasyarat yang dilakukan adalah uji normalitas dan uji homogenitas varians.

a. Uji Normalitas

Uji normalitas sebaran dilakukan untuk menyajikan bahwa sampel benar-benar berasal dari populasi yang berdistribusi normal. Uji normalitas dilakukan untuk menentukan langkah 
ISSN 2252-9063

Kumpulan Artikel Mahasiswa Pendidikan Teknik Informatika

(KARMAPATI)

Volume 8 Nomor 2 Tahun 2019

pengujian dengan menggunakan pengujian statistik parametrik atau non parametrik. Hipotesis yang akan diajukan adalah :

$\mathrm{H}_{0}$ : Tidak terdapat perbedaan frekuensi sebaran data prestasi belajar Sketsa pada kelompok eksperimen (normal)

$\mathrm{H}_{1}$ : Terdapat perbedaan frekuensi sebaran data prestasi belajar Sketsa pada kelompok eksperimen (tidak normal)

Uji normalitas data dilakukan dengan Kolmogorov-Smirnov dengan rumus seperti berikut.

$$
\mathrm{D}=\left|\mathrm{F}_{\mathrm{s}}(\mathrm{x})-\mathrm{F}_{\mathrm{t}}(\mathrm{x})\right| \max
$$

Keterangan :

$\begin{array}{llll}\mathrm{Fs}(\mathrm{x}): & \text { distribusi } & \text { frekuensi } & \text { kumulatif } \\ \mathrm{Ft}(\mathrm{x}): & \begin{array}{l}\text { distribusi } \\ \text { teoritis }\end{array} & \text { frekuensi } & \text { kumulatif } \\ & & & \end{array}$

Kriteria pengujian yang digunakan adalah data memiliki sebaran normal jika angka signifikansi yang dihasilkan lebih dari 0,05 dan dalam hal lain data tidak berdistribusi normal.

b. Uji Homogenitas Varians

Uji homogenitas ini dilakukan untuk mencari tingkat kehomogenan secara dua pihak yang diambil dari kelompok-kelompok terpisah dari satu populasi yaitu kelompok kontrol dan kelompok eksperimen. Untuk menguji homogenitas varians untuk kedua kelompok digunakan uji F, Hipotesis yang akan diujikan adalah :

$\mathrm{H}_{0}$ : Tidak terdapat perbedaan varians data prestasi belajar Sketsa antara kelompok eksperimen dan kelompok kontrol (homogen)

$\mathrm{H}_{1}$ : Terdapat perbedaan varians data prestasi belajar Sketsa antara kelompok eksperimen dan kelompok kontrol (tidak homogen)

Dengan rumus uji $\mathrm{F}$ seperti berikut

$$
F_{\text {hit }}=\frac{s_{1}{ }^{2}}{s_{2}{ }^{2}}
$$

Keterangan :

$\begin{array}{ll}\mathrm{S}_{1}{ }^{2} & \text { : varian terbesar } \\ \mathrm{S}_{2}{ }^{2} & \text { : varian terkecil }\end{array}$

Kriteria pengujian, jika $\mathrm{F}_{\text {hit }}<\mathrm{F} \alpha_{(\mathrm{n} 1-1, \mathrm{n} 2-1)}$ maka sampel homogen dapat melakukan pengujian dengan menggunakan rumus separated varians maupun polled varians dan jika $\mathrm{F}_{\text {hit }}>$ $\mathrm{F} \alpha_{(\mathrm{n} 1-1, \mathrm{n} 2-1)}$ maka sampel tidak homogen dapat melakukan pengujian dengan menggunakan rumus separated varians. Pengujian dilakukan pada taraf signifikan 5\% dengan derajat kebebasan untuk pembilang $\mathrm{n}_{1}-1$ dan derajat kebebasan untuk penyebut $\mathrm{n}_{2}-1$.

c. Uji Hipotesis Penelitian

Setelah dilakukan uji normalitas data dan uji homogenitas, maka dilanjutkan dengan pengujian hipotesis. Uji hipotesis digunakan untuk menguji hipotesis yang telah dilakukan pada penelitian ini, yaitu terdapat perbedaan prestasi belajar antara siswa yang menggunakan media E-learning Moodle dan siswa yang belajar menggunakan media PowerPoint pada mata pelajaran Sketsa di Kelas X DKV SMK Negeri 1 Sukasada. Pengujian hipotesis dijabarkan menjadi hipotesis nol $\left(\mathrm{H}_{0}\right)$ melawan hipotesis alternatif $\left(\mathrm{H}_{1}\right)$.

Secara statistik hipotesis tersebut dapat dirumuskan sebagai berikut :

$\mathrm{H}_{0}:{ }^{\mu_{1}}=\mu_{2}$ melawan $\mathrm{H}_{1}:{ }^{\mu_{1}}{ } \mu_{2}$

Artinya adalah :

$\mu_{1} \mu_{2}$ Tidak terdapat perbedaan prestasi belajar antara siswa yang menggunakan E-learning Moodle dan siswa yang belajar menggunakanmedia PowerPoint pada mata pelajaran sketsa di Kelas X DKV SMK Negeri 1 Sukasada.

$\mathrm{H}_{1}: \mu_{1 \neq} \mu_{2}: \begin{aligned} & \text { Terdapat perbedaan prestasi } \\ & \text { belajar antara siswa yang }\end{aligned}$ menggunakan E-learning Moodle dan siswa yang belajar menggunakan media PowerPoint pada mata pelajaran sketsa di Kelas X DKV SMK Negeri 1 Sukasada.

Keterangan :

$$
\begin{array}{ll}
\mu_{1}= & \begin{array}{l}
\text { Skor rata-rata hasil belajar siswa kelas } \\
\text { eksperimen }(\mathrm{KE})
\end{array} \\
\mu_{2}= & \begin{array}{l}
\text { Skor rata-rata hasil belajar siswa kelas } \\
\text { kontrol }(\mathrm{KK})
\end{array}
\end{array}
$$

Teknik analisis data yang digunakan untuk menguji hipotesis yaitu menganalisis perbedaan antara dua kelompok skor. Jika terbukti bahwa data yang dikumpulkan berdistribusi normal dan 
ISSN 2252-9063

Kumpulan Artikel Mahasiswa Pendidikan Teknik Informatika

(KARMAPATI)

Volume 8 Nomor 2 Tahun 2019

homogen ataupun tidak homogen, maka untuk menguji hipotesis pada penelitian ini akan digunakan uji-t dengan taraf signifikan 5\%. T-test yang digunakan adalah separated varian ataupun polled varian. Pengujian hipotesis menggunakan t-test, terdapat beberapa rumus yang digunakan rumus seperti berikut.

\section{Rumus (separated varians)}

$$
t=\frac{\overline{X_{1}}-\overline{X_{2}}}{\sqrt{\frac{s_{1}{ }^{2}}{n_{1}}+\frac{s_{2}{ }^{2}}{n_{2}}}}
$$

atau

$$
t=\frac{\text { Rumus (polled varians) }}{\sqrt{\frac{\left(n_{1}-1\right) s_{1}^{2}+\left(n_{2}-1\right) s_{2}^{2}}{n_{1}+n_{2}-2}\left(\frac{1}{n_{1}}+\frac{1}{n_{2}}\right)}}
$$

Keterangan :

$$
\begin{array}{ll}
\bar{X}_{1} & =\text { Nilai rata-rata skor kelompok eksperimen } \\
\bar{X}_{2} & =\text { Nilai rata-rata skor kelompok kontrol } \\
\mathrm{n}_{1} & =\text { Banyaknya kelompok eksperimen } \\
\mathrm{n}_{2} & =\text { Banyaknya kelompok kontrol } \\
\mathrm{S}_{1}^{2} & =\text { Varians kelompok eksperimen } \\
\mathrm{S}_{2}^{2} & =\text { Varians kelompok kontrol }
\end{array}
$$

Pedoman penggunaan rumus-rumus t-test separated varian, dan polled varian yaitu sebagai berikut :

a. Bila jumlah siswa $\mathrm{n}_{1}=\mathrm{n}_{2}$, varian homogen maka dapat digunakan rumus t-test baik untuk separated varian maupun polled varian. Untuk melihat harga t-tabel digunakan derajat kebebasan $(\mathrm{dk})=\mathrm{n}_{1}+\mathrm{n}_{2}-$ 2

b. Bila jumlah siswa $\mathrm{n}_{1} \neq \mathrm{n}_{2}$, varian homogen maka dapat digunakan rumus t-test dengan polled varian. Untuk melihat harga t-tabel digunakan derajat kebebasan $(\mathrm{dk})=\mathrm{n}_{1}+\mathrm{n}_{2}-$ 2

c. Bila jumlah siswa $\mathrm{n}_{1}=\mathrm{n}_{2}$, varian tidak homogen dapat digunakan rumus t-test dengan separated varian dan polled varian. Untuk melihat harga t-tabel digunakan derajat kebebasan $(\mathrm{dk})=\mathrm{n}_{1}-1$ atau $\mathrm{n}_{2}-1$

d. Bila jumlah siswa $\mathrm{n}_{1} \neq \mathrm{n}_{2}$, varian tidak homogen untuk ini digunakan t-test dengan separated varian. Harga t sebagai pengganti t-tabel dihitung dari selisih harga t-tabel dengan $d k\left(n_{1}-1\right)$ dan $d k\left(n_{2}-1\right)$ dibagi dua, dan kemudian ditambahkan dengan harga $t$ yang terkecil.

Untuk mendapatkan hasil yang lebih akurat analisis uji-t dilakukan dengan dua cara yaitu secara manual dan dengan bantuan program SPSS 16 for Windows. Apabila cara manual untuk menghasilkan interpretasi, maka $t_{\text {hitung }}$ tersebut harus dikomparasi dengan $t_{\text {tabel }}$ dengan indikator taraf signifikan $5 \%(0,05)$. Apabila $t_{\text {hitung lebih }}$ besar dari pada $t_{\text {tabel }}\left(t_{\text {hitung }}>t_{\text {tabel }}\right)$ maka terdapat perbedaan yang signifikan antara kedua variabel atau sampel. Sedangkan apabila $t_{\text {hitung }}$ lebih kecil dari pada $t_{\text {tabel }}\left(t_{\text {hitung }}<t_{\text {tabel }}\right)$ maka tidak terdapat perbedaan yang signifikan antara kedua variabel atau sampel. Sedangkan hasil interpretasi output program SPSS 16.0 for Windows dilakukan dengan melihat nilai signifikansi. Angka signifikansi lebih kecil dari 0,05 berarti $\mathrm{H}_{0}$ ditolak dan artinya terdapat perbedaan variabel bebas antar kelompok.

\section{HASIL DAN PEMBAHASAN}

\section{A. Hasil Penelitian}

Berdasarkan data pengukuran hasil belajar kognitif terhadap 27 siswa kelompok eksperimen, diperoleh data distribusi frekuensi skor post-test hasil belajar kognitif kelompok eksperimen, diketahui bahwa skor tertinggi siswa adalah 38 dan skor terendah siswa adalah 24 dengan rentangan 14, banyak kelas interval 6 dan panjang kelas interval adalah 3. Rata-rata atau mean (M) hasil yang dicapai siswa pada kelas eksperimen sebesar 31,8889 . Kategori skor data prestasi belajar siswa kelas eksperimen dilihat pada Gambar 3.

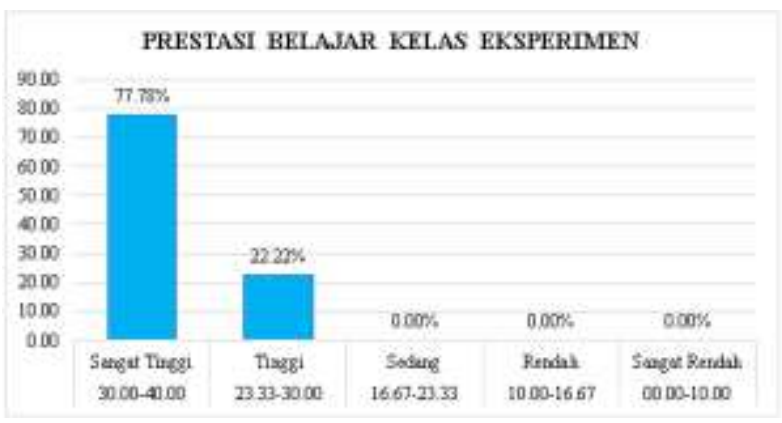

Gambar 3. Histogram Prestasi Belajar Kelompok Eksperimen

Berdasarkan data pengukuran prestasi belajar kognitif terhadap 28 siswa kelompok kontrol, diperoleh data distribusi frekuensi skor post-test hasil belajar kognitif kelompok kontrol, diketahui bahwa skor tertinggi siswa adalah 34 dan skor terendah siswa adalah 
ISSN 2252-9063

Kumpulan Artikel Mahasiswa Pendidikan Teknik Informatika

(KARMAPATI)

Volume 8 Nomor 2 Tahun 2019

20 dengan rentangan 14, banyak kelas interval 6 dan panjang kelas interval adalah 3. Rata-rata atau mean (M) hasil belajar yang dicapai siswa pada kelas kontrol sebesar 27 Kategori skor data prestasi belajar siswa kelas kontrol dilihat pada Gambar 4.

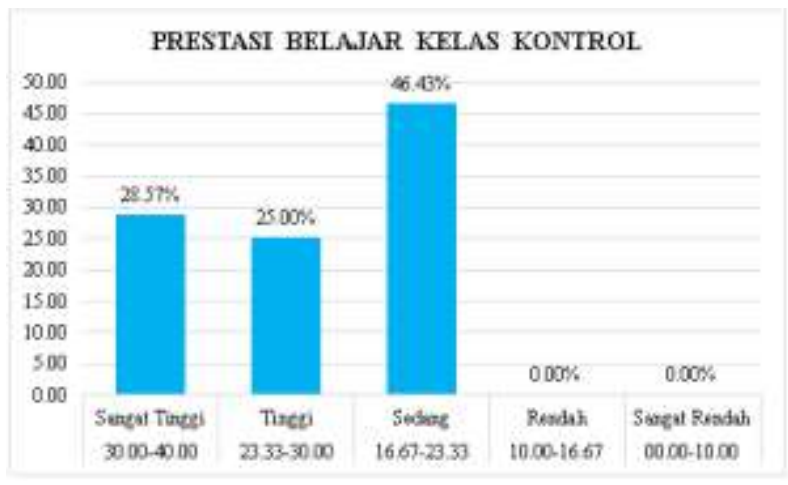

Gambar 4. Histogram Prestasi Belajar Kelompok Kontrol

Perhitungan uji prasyarat dilakukan dalam dua buah uji yakni uji normalitas dan uji homogenitas. Berdasarkan hasil output analisis uji normalitas menunjukkan nilai Kolmogrov-Sminov dengan probabilitas (sig) sebesar 0,200 dan nilai Shapiro Wilk dengan probabilitas (a) sebesar 0.340 , oleh karena nilai probabilitas kedua nilai signifikan $>0,05$ maka ini berarti bahwa data hasil posttest kelompok eksperimen berdistribusi normal yaitu tidak terdapat perbedaan frekuensi sebaran data prestasi belajar Sketsa pada kelompok eksperimen (normal). Berdasarkan hasil output analisis uji normalitas kelompok kontrol menunjukkan nilai Kolmogrov-Sminov dengan probabilitas (sig) sebesar 0.200 dan nilai Shapiro Wilk dengan probabilitas (a) sebesar 0.320 , oleh karena nilai probabilitas kedua nilai signifikan $>0,05$ maka ini berarti bahwa data hasil posttest kelompok kontrol berdistribusi normal yaitu tidak terdapat perbedaan frekuensi sebaran data hasil belajar Sketsa pada kelompok kontrol (normal).

Perhitungan selanjutnya adalah uji homogenitas, berdasarkan hasil output analisis menunjukkan nilai signifikan sebesar 0.439 , oleh karena nilai signifikan > 0,05 maka data hasil belajar kelompok eksperimen dan kelompok kontrol dikatakan homogen yaitu Tidak terdapat perbedaan varians data prestasi belajar Sketsa antara kelompok eksperimen dan kelompok kontrol (homogen).

Karena data kelas eksperimen dan kelas kontrol telah berdistribusi normal dan data homogen maka dilanjutkan dengan melakukan uji hipotesis dengan menggunakan uji-t. Uji-t dapat dihitung dengan menggunakan Microsoft Excel 2016 dan SPSS 16.0 dengan hasil yang tidak jauh berbeda. Uji-t dihitung menggunakan rumus Polled Varians memperoleh thitung dengan Microsoft Excel 2016 sebesar 4,519 dan dengan menggunakan SPSS 16.0 sebesar 4,509. Nilai $\mathrm{t}_{\text {tabel }}$ dengan db 55-2 = 53 adalah sebesar 2,006 dengan menggunakan Microsoft Excel 2016 dan sebesar 2,005 dengan menggunakan SPSS 16.0.

Berdasarkan perhitungan uji-t dengan SPSS 16.0 diperoleh $t_{\text {hitung }}>\mathrm{t}_{\text {tabel }}$ yaitu 4,509 > 2,005 maka $\mathrm{H}_{0}$ ditolak, berarti $\mathrm{H}_{1}$ diterima. Berdasarkan hal ini dapat diartikan bahwa tidak terdapat perbedaan prestasi belajar antara siswa yang menggunakan media E-learning Moodle dan siswa yang belajar menggunakan media PowerPoint pada mata pelajaran Sketsa di Kelas X DKV SMK Negeri 1 Sukasada dinyatakan ditolak, dengan demikian $\mathrm{H}_{1}$ yang menyatakan terdapat perbedaan prestasi belajar antara siswa yang menggunakan media E-learning Moodle dan siswa yang belajar menggunakan media PowerPoint pada mata pelajaran Sketsa di Kelas $X$ DKV SMK Negeri 1 Sukasada dinyatakan diterima. Uji-t juga dihitung dengan menggunakan SPSS 16.0 dengan hasil sebagai berikut:

Tabel 6. Hasil Uji Hipotesis dengan SPSS

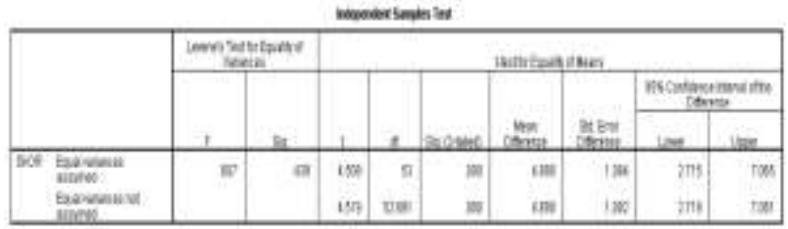

Berdasarkan hasil perhitungan posttest kelompok eksperimen dan kelompok kontrol dengan menggunakan SPSS 16.0 dari output analisis menunjukan nilai sig. sebesar 0,000. Oleh karena nilai probabilitas signifikan $<0,05$ maka $\mathrm{H}_{0}$ ditolak atau $\mathrm{H}_{1}$ diterima. Sehingga dapat dikatakan bahwa terdapat perbedaan prestasi belajar antara siswa yang menggunakan E-learning Moodle dan siswa yang belajar menggunakan media PowerPoint pada mata pelajaran sketsa di Kelas X DKV SMK Negeri 1 Sukasada.

Data dari hasil respon siswa terhadap penggunaan media pembelajaran E-learning Moodle pada mata pelajaran Sketsa terhadap 27 siswa kelompok eksperimen memiliki rata-rata 83,04 dan diketahui bahwa respon siswa terhadap penggunaan media pembelajaran E-learning Moodle terhadap mata pelajaran Sketsa sebanyak $77,78 \%$ berkategori sangat positif, dan sebanyak $22,22 \%$ berkategori positif, serta tidak ada respon penggunaan media pembelajaran $E$ learning Moodle yang berkategori cukup positif, kurang positif dan sangat kurang positif. Hasil respon siswa untuk lebih jelas dapat dilihat pada Gambar 5. 
ISSN 2252-9063

Kumpulan Artikel Mahasiswa Pendidikan Teknik Informatika

(KARMAPATI)

Volume 8 Nomor 2 Tahun 2019

\section{PERSENTASE RESPON SISWA}

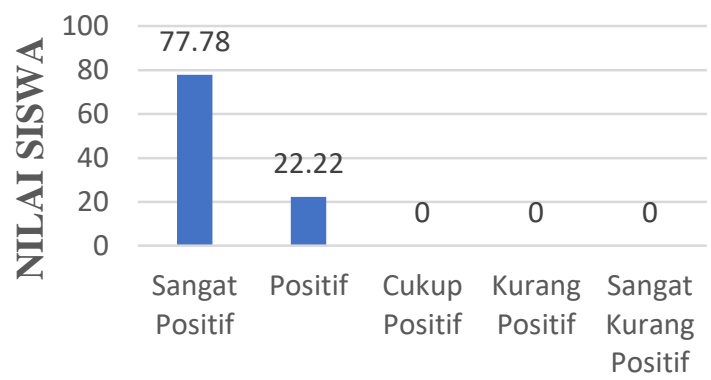

\section{KATEGORI}

\section{Gambar 5. Histogram Respon Siswa}

\section{B. Pembahasan}

Hasil penelitian meliputi analisis deskriptif dan analisis statistic yang mengungkap pengaruh variable bebas terhadap variable terikat. Variabel bebas dalam penelitian ini adalah media pembelajaran E-learning Moodle sedangkan variable terikat dalam penelitian ini adalah prestasi belajar pada mata pelajaran Sketsa.

Sebelum menentukan anggota sampel, terlebih dahulu menentukan anggota populasi. Anggota populasi dalam penelitian ini adalah siswa kelas $\mathrm{X}$ Desain Komunikasi Visual yang terdiri dari kelas X DKV 1, X DKV 2 di SMK Negeri 1 Sukasada. Jumlah anggota populasi yang telah ditentukan dalam penelitian ini adalah 55 siswa. Dalam penelitian ini, pemilihan sampel yang digunakan sebagai kelas eksperimen dan kelas kontrol dilakukan uji kesetaraan terlebih dahulu untuk meyakinkan bahwa kelas benar-benar dalam keadaan setara dari segi kemampuan akademisnya. Setara dalam artian pengelompokan siswa ke dalam kelas-kelas tersebut disebar secara merata antara siswa yang memiliki kemampuan tinggi, sedang, dan rendah. Uji kesetaraan dilakukan terhadap dua kelas dengan menggunakan nilai Ulangan Akhir Semester tahun pelajaran 2018/2019 semester ganjil. Hasil tes ulangan akhir semester yang dianalisis adalah hasil murni dalam artian nilai belum mendapatkan perlakuan remedial.

Setelah mendapatkan hasil yang setara selanjutnya dilakukan teknik Simple Random Sampling untuk menentukan kelas yang akan digunakan sebagai sampel. Hasil pengundian didapatkan bahwa kelas X DKV 1 sebagai kelas eksperimen dan X DKV 2 adalah kelas kontrol. Kelas eksperimen adalah kelompok yang diberi perlakuan yaitu dengan pembelajaran yang menggunakan media pembelajaran E-learning Moodle. Kelas kontrol adalah kelompok siswa yang belajar dengan media pembelajaran power point. Penelitian ini dilaksanakan dalam 5 kali pertemuan, yang terdiri dari 4 kali proses pembelajaran dan 1 kali pertemuan untuk posttest yang dilakukan pada kelas eksperimen dan kontrol.

Analisis prestasi belajar yang dilakukan pada penelitian ini adalah ranah kognitif. Setelah diberikan perlakuan, selanjutnya diberikan tes akhir pada kelas eksperimen dan kelas kontrol dengan tujuan untuk mengetahui hasil belajar siswa setelah diberi perlakuan. Analisis dari hasil penelitian didapat bahwa rata-rata posttest prestasi belajar Sketsa yang dicapai siswa pada kelompok eksperimen adalah 31,93 sedangkan rata-rata posttest hasil belajar Sketsa untuk kelompok kontrol sebesar 27,04. Dengan demikian, rata-rata posttest prestasi belajar Sketsa pada kelompok eksperimen lebih besar dibandingkan kelompok kontrol. Untuk perhitungan normalitas, homogenitas, dan uji-t menggunakan Microsoft excel dan SPSS hasilnya tidak jauh berbeda, dimana kedua kelompok baik kelompok eksperimen dan kelompok kontrol memiliki data yang normal dan homogen.

Perhitungan Uji hipotesis dengan uji-t menggunakan Microsoft Excel dengan taraf signifikansi $5 \%$ dan derajat kebebasan 53 diperoleh thitung $=4,519$ dan ttabel $=2,006$. Karena thitung $>$ ttabel maka $\mathrm{H}_{0}$ ditolak dan $\mathrm{H}_{1}$ diterima. Sedangkan analisis uji-t dengan SPSS mendapat hasil thitung sebesar 0.000 dengan taraf signifikan $5 \%$. Oleh karena itu hasil probabilitas signifikan $<0,05$ maka $\mathrm{H}_{0}$ ditolak dan $\mathrm{H}_{1}$ diterima. Berarti kedua temuan tersebut menunjukkan bahwa Terdapat perbedaan prestasi belajar antara siswa yang menggunakan E-learning Moodle dan siswa yang belajar menggunakan media PowerPoint pada mata pelajaran sketsa di Kelas X DKV SMK Negeri 1 Sukasada.

Berdasarkan analisis hasil penelitian dan pembahasan menunjukkan bahwa terdapat perbedaan prestasi belajar siswa pada kelas eksperimen dan kelas kontrol setelah dilakukan pembelajaran dengan menggunakan media pembelajaran E-learning Moodle. Hal ini disebabkan oleh adanya media pembelajaran yang membantu siswa dalam memahami materi yang diajarkan oleh guru dan proses pembelajaran di dalam kelas tidak selalu berpusat lagi kepada guru sehingga bahan pembelajaran yang digunakan tidak terbatas khususnya pada mata pelajaran Sketsa dan dapat membantu siswa belajar secara mandiri tidak terlalu menggantungkan belajar dari catatan saja.

Hasil penelitian terhadap pengaruh E-learning Moodle pada mata pelajaran Sketsa ini sejalan dengan penelitian oleh [4] tentang pengaruh media pembelajaran E-learning Moodle dan motivasi terhadap prestasi belajar siswa pada mata pelajaran pengoperasian perangkat lunak lembar sebar, yang mengatakan bahwa E-Learning Moodle adalah sebuah media yang tepat, karena diharapkan siswa dapat lebih termotivasi untuk 
belajar mandiri tanpa perlu bimbingan seorang guru secara langsung. Hasil akhir yang didapatkan menunjukkan perbandingan yang lebih baik prestasi belajar pengoperasian perangkat lunak lembar sebar pada siswa yang diajarkan dengan media E-learning Moodle dibandingkan dengan siswa yang diajarkan dengan media pembelajaran LKS.

Hal ini sesuai juga dengan pendapat menurut [5] menyatakan bahwa manfaat dari penggunaan moodle sangat penting, salah satunya adalah mengatasi keterbatasan frekuensi tatap muka antara siswa dengan para guru tanpa dibatasi ruang dan waktu. Bahan pembelajaran yang tak terbatas khususnya pada materi tentang pondasi dapat membantu siswa belajar secara mandiri dan tidak terlalu menggantungkan belajar dari catatan saja. Hal ini juga didukung teori yang disampaikan [9] tentang Pengaruh media pembelajaran E-learning Moodle terhadap hasil belajar siswa pada bidang TKJ, yang menyatakan bahwa pemanfaatan Media Moodle dapat menarik minat siswa dalam mengerjakan suatu tugas yang diberikan oleh guru selain itu dengan penerapan Pembelajaran berbasis media ini memiliki potensi yang cukup untuk memenuhi tuntutan belajar pada proses pembelajaran. Kurniawan juga memberikan beberapa saran terhadap penelitian yang dilakuakan yaitu : (1) penggunaan media pembelajaran E-learning Moodle sangat tepat digunakan untuk meningkatkan hasil belajar siswa dibandingkan siswa yang diajarkan dengan metode konvensional; dan (2) Penggunaan media pembelajaran E-learning Moodle harus diadakan guru dan siswa di satu sekolah, tidak hanya dalam satu kelas.

Hasil analisis respon siswa terhadap penerapan media pembelajaran E-learning Moodle berada pada kategori sangat positif yaitu skor rata-rata respon siswa yang diperoleh sebesar 83,04 dengan persentase yang didapat sebesar $77,78 \%$ siswa memberikan respon sangat positif dan $22,22 \%$ siswa memberikan respon positif. Keadaan seperti ini dapat dijadikan modal untuk menciptakan suasana belajar yang efektif agar bisa meningkatkan hasil belajar siswa yang lebih tinggi. Respon positif siswa akan menjadi langkah awal untuk menuju kepada lingkungan belajar yang efektif. Jadi, dengan diperoleh respon siswa yang sangat positif terhadap penggunaan E-learning Moodle pada mata pelajaran Sketsa di dalam kelas dapat mengindikasikan bahwa E-learning Moodle ini dapat diterima dengan baik oleh siswa. Oleh karena itu, penggunaan E-learning Moodle pada mata pelajaran Sketsa ini dapat dijadikan sebagai langkah alternative dalam pembelajaran di kelas khususnya dalam pelajaran Sketsa.

fitur yang paling berpengaruh dalam proses pembelajaran dengan menggunakan media E-learning
Moodle terdapat pada fitur Assignment, Quiz, dan Forum. Pada fitur Assignment guru dapat memberikan penugasan kepada siswa secara online, dengan mengakses materi yang diberikan berupa tutorial, video, dan referensi terkait lainnya yang dapat mendukung dari penjelasan guru yang tidak dapat di mengerti langsung oleh siswa. Kemudian fitur selanjutnya yaitu Quiz, melalui fitur quiz ini siswa dapat mengukur seberapa jauh pemahamannya terhadap materi yang disampaikan. Dengan fitur quiz yang terdapat pada E-learning Moodle membantu guru untuk lebih efisien dan efektif dalam proses pembelajaran. Dan fitur selanjutnya adalah Forum diskusi, melalui forum diskusi yang diberikan oleh guru di setiap kegiatan pembelajaran dapat dimanfaatkan oleh siswa untuk mendiskusikan hasil presentasi atau menanyakan tugas terkait yang belum dimengerti siswa, sering kali dalam proses diskusi pada saat presentasi di depan kelas, siswa ragu dalam menyampaikan pendapat. Maka solusi yang diberikan yaitu dengan memanfaat fitur forum diskusi untuk memfasilitasi siswa dalam menyampaikan pendapat atau pertanyaannya.

Dalam penelitian ini adapun kendala-kendala yang dihadapi peneliti saat menerapkan E-learning Moodle adalah 1) siswa belum terbiasa dalam mengimplementasikan E-learning Moodle, sehingga saat guru meminta siswa untuk menggunakan E-learning Moodle terdapat kendala yang masih dialami siswa seperti lupa dengan username dan password. Solusi yang diberikan terhadap kendala ini adalah mahasiswa selaku peneliti selalu mengingatkan siswa agar menyimpan akses login yang mereka gunakan pada Smartphone/Android mereka masing-masing agar nanti ketika ingin login kembali hanya tinggal memilih username yang sudah tersimpan sebelumnya. 2) Guru selaku Kepala bengkel jurusan Desain Komunikasi Visual (DKV) sering kali memiliki kesibukan yang tidak dapat ditinggalkan sehingga tidak jarang pembelajaran dimulai lebih lambat dari pada waktu yang sudah ditentukan. Guru memiliki kesibukan yang tidak dapat ditinggalkan sehingga tidak jarang pembelajaran dimulai lebih lambat daripada waktu yang sudah ditentukan. Solusi yang diberikan terhadap kendala ini adalah, mahasiswa selaku peneliti mengarahkan siswa untuk tetap mempelajari materi yang sudah tersedia pada $E$ learning Moodle sehingga pelaksanaan pembelajaran dapat berlangsung dengan baik. 3) karakteristik yang dimiliki siswa di dalam kelas berbeda-beda, ada yang sangat menonjolkan dirinya untuk lebih aktif selama proses pembelajaran ada juga yang biasa-biasa saja, sehingga dalam hal tersebut tidak semua siswa memiliki karakteristik motivasi belajar yang tinggi. Solusi yang diberikan terhadap kendala ini adalah, mahasiswa selaku peneliti harus lebih memperhatikan aktivitas siswa tersebut selama proses pembelajaran di dalam kelas 
ISSN 2252-9063

Kumpulan Artikel Mahasiswa Pendidikan Teknik Informatika

(KARMAPATI)

Volume 8 Nomor 2 Tahun 2019

dengan memberikan pendampingan atau arahan yang lebih dan mengarahkan step by step yang harus dikerjakan oleh siswa tersebut.

Berdasarkan pertimbangan-pertimbangan teoritik dan operasional, maka implikasi dari penelitian ini jika dilihat dari teori konstruktivisme adalah siswa dituntun lebih aktif dalam proses pembelajaran dikelas karena dalam hal ini siswa menjadi pusat kegiatan pembelajaran di dalam kelas (student learning center). Penyampaian materi yang diberikan oleh guru harus dapat lebih dikembangkan oleh siswa, dengan cara mencari atau menggali lebih dalam tentang materi yang belum diketahui dan mengaplikasikan ide-ide yang mereka miliki sehingga hasil belajar dapat dicapai dengan lebih baik. Dalam penelitian ini media pembelajaran yang dapat digunakan untuk mencapai hasil belajar lebih baik dengan menggunakan media E-learning Moodle pada mata pelajaran Sketsa.

Kemudian jika dilihat dari teori Cone Experience Dale (kerucut pengalaman Dale) tersebut pengalaman siswa selama mengikuti proses pembelajaran di dalam kelas dapat diukur tingkat pemahamannya dari hanya dapat mengingat sebesar $10 \%$ jika belajar dengan cara membaca, $20 \%$ jika belajar dengan cara mendengar, $30 \%$ jika belajar dengan cara melihat gambar atau video, $50 \%$ jika belajar dengan cara diskusi, $70 \%$ jika kita belajar dengan cara presentasi, dan $90 \%$ jika belajar dengan cara simulasi dan kerja nyata. Jika dikaitkan dengan kerucut pengalaman, maka proses pembelajaran yang dilakukan dengan media pembelajaran E-learning Moodle dan metode yang digunakan berada pada tingkatan keterlibatan (Menyajikan/Presentasi) yang memiliki daya ingat terhadap materi sebesar $70 \%$.

\section{SIMPULAN}

Berdasarkan hasil penelitian dan pembahasan, dapat dikemukakan beberapa simpulan. Adapun simpulan yang akan dikemukakan dalam penelitian ini adalah sebagai berikut.

1. Terdapat perbedaan prestasi belajar antara siswa yang menggunakan media E-learning Moodle dan siswa yang belajar menggunakan media PowerPoint pada mata pelajaran Sketsa di Kelas X DKV SMK Negeri 1 Sukasada. Dilihat dari rata-rata prestasi belajar posttest kelompok eksperimen dengan penerapan E-learning Moodle adalah 31,93 sedangkan rata-rata posttest kelompok kontrol sebesar 27,04. Artinya pembelajaran yang menggunakan media E-learning Moodle memberikan pengaruh yang signifikan (positif) terhadap prestasi belajar siswa.
2. Terdapat hasil analisis respon siswa dari penerapan media pembelajaran E-learning Moodle pada mata pelajaran Sketsa dengan rata-rata skor respon siswa sebesar 83,04 adalah termasuk dalam kategori sangat positif. Persentase respon siswa terhadap penggunaan media pembelajaran E-learning Moodle sebesar $77,78 \%$ sangat positif, dan $22,22 \%$ positif. Sehingga pembelajaran menggunakan $E$ learning Moodle baik untuk diterapkan dalam proses pembelajaran.

Adapun saran yang dapat disajikan berdasarkan hasil penelitian yang telah dilakukan adalah sebagai berikut :

1. Bagi Sekolah Diharapkan dapat membantu untuk mensosialisasikan kepada guru lain untuk menerapkan dan mencoba menggunakan $E$ learning Moodle sebagai salat satu alternatif pembelajaran dalam proses belajar mengajar.

2. Wakasek Sarana dan Prasarana Diharapkan dapat menyediakan fasilitas-fasilitas pendukung dalam penerapan pembelajaran menggunakan E-learning Moodle di setiap jurusan.

3. Bagi Guru Diharapkan untuk menerapkan pembelajaran menggunakan E-learning Moodle sebagai salah satu alternatif pembelajaran dalam proses belajar mengajar di kelas mengingat E-learning Moodle memberikan pengaruh positif terhadap hasil belajar siswa dan untuk siswa yang sudah pernah menggunakan E-learning Moodle agar dibiasakan menggunakannya dalam proses pembelajaran.

4. Bagi peneliti selanjutnya Penelitian ini dilakukan dengan berbagai keterbatasan, terutama kondisi kelas, siswa, dan materi yang digunakan. Disarankan untuk peneliti yang tertarik dapat melakukan penelitian dengan $E$ learning Moodle untuk mata pelajaran yang berbeda dan pada jenjang yang berbeda. Selama proses penelitian berlangsung, peneliti mendapatkan saran yang diberikan oleh guru pengampu mata pelajaran Sketsa terkait dengan media E-learning Moodle yang digunakan, yaitu agar dapat membuat template pada $E$ learning Moodle terlihat lebih mudah dan simple agar siswa lebih mengerti dalam menggunakan E-learning Moodle. Sehingga untuk penelitian selanjutnya bisa dilakukan pengembangan terkait dengan media pembelajaran E-learning Moodle. 


\section{REFERENCES}

[1] Munir, Pembelajaran Jarak Jauh Berbasis Teknologi Informasi dan Komunikasi, Jakarta: CV. Alfabeta, 2009.

[2] Sutirman, Media \& Model-model Pembelajaran Inovatif, Yogyakarta: Graha Ilmu, 2013.

[3] Samsuddin, "Pemanfaatan E-learning Moodle Pada Mata Pelajaran Matematika Di SMK Negeri 5 Makasar," Jurnal Komunikasi KAREBA, p. Vol.2 No.1, 2013.

[4] Fadillah, "Pengaruh Media Pembelajaran (Elearning Moodle, LKS) dan Motivasi Terhadap Hasil Belajar Pengoperasian Perangkat Lunak Lembar Sebar Di SMK Negeri 1 Mojokerto," Jurnal Pendidikan Vokasi, pp. Vol.2 No.1 ISSN:2302-285X, 2014.

[5] Pranoto, "Penerapan Media Pembelajaran Elearning Berbasis Moodle Pada Mata Pelajaran Ilmu Bangunan Gedung Di Kelas X TGB SMKN 1 KEDIRI," Jurnal Kajian Pendidikan Teknik Bangunan, pp. Vol.3 No.3 13-19, 2015.

[6] d. Ramadhany, "Pengaruh Penggunaan Model Pembelajaran Project Based Learning Pada Pembelajaran Sejarah Terhadap Hasil Belajar Siswa Kelas XI IPS MAN Temanggung," Universitas Negeri Semarang, 2016.

[7] Nugroho, "Menerapkan Teori Kerucut Pengalaman Edgals Dale Dalam Diklat," Jumat Juli 2017. [Online]. Available: http://bppk.kemenkeu.go.id/id/berita-pajak/24087menerapkan-teori-kerucut-pengalaman-edgalsdale-dalam-diklat.

[8] I. M. Candiasa, Statistik Multivariat Disertai Aplikasi SPSS, Singaraja: Unit Penerbit Undiksha, 2010 .

[9] Kurniawan, "Pengaruh Penerapan Media Pembelajaran Moodle Terhadap Hasil Belajar Siswa Pada Bidang Kejuruan TKJ Di SMKN 3 Buduran," Jurnal IT-EDU, p. Vol.2 No.1, 2017. 